\title{
Arenibacter nanhaiticus sp. nov., isolated from marine sediment of the South China Sea
}

\author{
Fengqin Sun,† Baojiang Wang,† Yaping Du, Xiupian Liu, Qiliang Lai, \\ Guangyu Li, Jie Luo and Zongze Shao
}

\author{
Correspondence \\ Zongze Shao \\ shaozz@163.com
}

\author{
Key Laboratory of Marine Biogenetic Resources, The Third Institute of Oceanography, State \\ Oceanic Administration, Xiamen 361005, PR China
}

The South China Sea is a marginal sea in the south of China. It is a part of the Pacific Ocean, encompassing an area from Singapore to the Strait of Taiwan of around $3,500,000 \mathrm{~km}^{2}$. It is one of the largest sea bodies after the five oceans and it has a remarkable amount of biological diversity. According to studies made by the Department of Environment and Natural Resources, The Philippines, this body of water holds one third of the world's marine biodiversity, thereby making it a very important ecosystem.

The genus Arenibacter belongs to the family Flavobacteriaceae within the phylum 'Bacteroidetes' and was proposed by Ivanova et al. (2001). Currently, it accommodates five species: Arenibacter latericius, $A$. troitsensis, A. certesii, A. palladensis and A. echinorum (Ivanova et al., 2001; Nedashkovskaya et al., 2003, 2004, $2006,2007)$. The recent isolation of novel species of the genus Arenibacter led Nedashkovskaya et al. (2006) to emend the description of the genus Arenibacter. In this study, a dark-orange-pigmented marine bacterial strain, $\mathrm{NH} 36 \mathrm{~A}^{\mathrm{T}}$, which is considered to be an Arenibacter-like organism on the basis of 16S rRNA gene sequence comparison results, is described. Accordingly, the aim of the present work was to establish the exact taxonomic position of strain $\mathrm{NH}_{36 \mathrm{~A}^{\mathrm{T}}}$ by using a polyphasic approach involving phenotypic, genetic and chemotaxonomic analyses.

†These authors contributed equally to this work.

The GenBank/EMBL/DDBJ accession number for the 16S rRNA gene sequence of Arenibacter nanhaiticus $\mathrm{NH} 6 \mathrm{~A}^{\top}$ is EU999955.
Strain $\mathrm{NH} 36 \mathrm{~A}^{\mathrm{T}}$ was isolated from a sandy sediment sample containing shell fragments collected from a water depth of $36 \mathrm{~m}$ in the South China Sea $\left(19^{\circ} 44.775^{\prime} \mathrm{N} 111^{\circ} 6.192^{\prime} \mathrm{E}\right)$ in May 2007. The supernatant of sediment slurry was diluted and spread on M2 agar plates, which were then incubated at $25{ }^{\circ} \mathrm{C}$ for 1 week. M2 contained (per litre of seawater): $5 \mathrm{~g} \mathrm{CH}_{3} \mathrm{COONa}, 0.5 \mathrm{~g}$ peptone, $0.5 \mathrm{~g}$ yeast extract, $0.5 \mathrm{~g}$ glucose, $0.5 \mathrm{~g}$ sucrose, $0.5 \mathrm{~g}$ starch, $0.05 \mathrm{~g}$ trisodium citrate, $0.05 \mathrm{~g}$ malic acid, $0.05 \mathrm{~g}$ potassium sodium tartrate, $1 \mathrm{~g} \mathrm{NH}_{4} \mathrm{NO}_{3}, 0.2 \mathrm{~g} \mathrm{NH}_{4} \mathrm{Cl}$ and $15 \mathrm{~g}$ agar, adjusted to about $\mathrm{pH}$ 7.5-7.6. Strain $\mathrm{NH} 36 \mathrm{~A}^{\mathrm{T}}$ was picked out and subsequently purified three times on M2 by streaking. The strain was obtained from the plate by gently scraping the surface of the medium and preserved as a $20 \%$ $(\mathrm{v} / \mathrm{v})$ glycerol suspension at $-80{ }^{\circ} \mathrm{C}$. Cell morphology was examined by light microscopy (model 50i; Nikon) and transmission electron microscopy (model JEM-1230; JEOL) using cells from exponentially growing cultures.

Growth in the absence of $\mathrm{NaCl}$ was investigated in $\mathrm{M} 2$ medium lacking $\mathrm{Na}^{+}$. Growth at various $\mathrm{NaCl}$ concentrations $(0.5-8.0 \%$, w $/ v$, at $0.5 \%$ intervals and $8-25 \%$, w/v, at $2 \%$ intervals) was investigated in M2 medium. Growth at different temperatures $\left(4,10,15,20,25,30,35,40,45{ }^{\circ} \mathrm{C}\right)$ was measured on M2 medium. The initial $\mathrm{pH}$ range for growth was determined in $5 \mathrm{ml}$ HLB medium supplemented with $200 \mu \mathrm{l} \mathrm{M} 2$ medium, which was adjusted to various $\mathrm{pH}$ (2.5-10.0 at intervals of 0.5) using $\mathrm{HCl}(5 \mathrm{M})$ and $\mathrm{NaOH}(5 \mathrm{M})$. HLB was modified from Luria-Bertani medium (Sambrook et al., 1989), with the concentration of $\mathrm{NaCl}$ increased to $30 \mathrm{~g} \mathrm{l}^{-1}$. Growth was measured spectrophotometrically at $600 \mathrm{~nm}$ after incubation for 2 days. The 
presence of flexirubin-type pigments was investigated as described by Christakis et al. (2005). The oxidase reaction was tested by using oxidase reagent (bioMérieux). Catalase activity was tested using a $3 \% \mathrm{H}_{2} \mathrm{O}_{2}$ solution. Hydrolysis of starch, Tween 20, Tween 40 and Tween 80 was determined as described by Cowan \& Steel (1965). Degradation of alginate, cellulose and chitin was tested as described previously (Ivanova et al., 2001). Other physiological and biochemical tests were performed with the API $20 \mathrm{E}$ and API 20NE systems (bioMérieux); the $\mathrm{NaCl}$ concentration was increased to $30 \mathrm{~g} \mathrm{l}^{-1}$ in API $\mathrm{NaCl}$ medium (bioMérieux). The API ZYM system (bioMérieux) was used to determine the activity of some enzymes. Oxidation of various substrates was determined by using the Biolog system as described previously (Ivanova et al., 1998). GN2 microplates were selected and, after adding $150 \mu$ liquid culture with the $\mathrm{NaCl}$ concentration increased to $2.4 \%$, plates were incubated at $30{ }^{\circ} \mathrm{C}$.

Susceptibility to different antibiotics was tested on M2 agar plates by using discs (Oxoid) containing the following compounds: ceftriaxone $(30 \mu \mathrm{g})$, cephradine $(30 \mu \mathrm{g})$, chloramphenicol $(30 \mu \mathrm{g})$, gentamicin $(10 \mu \mathrm{g})$, erythromycin $(15 \mu \mathrm{g})$, cefoperazone $(75 \mu \mathrm{g})$, ciprofloxacin $(5 \mu \mathrm{g})$, clindamycin $(2 \mu \mathrm{g})$, doxycycline hydrochloride $(30 \mu \mathrm{g})$, neomycin $(10 \mu \mathrm{g})$, tetracycline $(30 \mu \mathrm{g})$, cephalexin $(30 \mu \mathrm{g})$, ampicillin $(10 \mu \mathrm{g})$, furazolidone $(15 \mu \mathrm{g})$, metronidazole $(5 \mu \mathrm{g})$, cephazolin $(30 \mu \mathrm{g})$, lincomycin $(2 \mu \mathrm{g})$, minocycline
$(30 \mu \mathrm{g})$, norfloxacin $(10 \mu \mathrm{g})$, kanamycin $(30 \mu \mathrm{g})$, vancomycin $(30 \mu \mathrm{g})$, trimethoprim $(25 \mu \mathrm{g})$, piperacillin $(100 \mu \mathrm{g})$, ofloxacin $(5 \mu \mathrm{g})$, rifampicin $(5 \mu \mathrm{g})$, carbenicillin $(100 \mu \mathrm{g})$, polymyxin $\mathrm{B}(300 \mathrm{U})$, streptomycin $(10 \mu \mathrm{g})$, oxacillin $(1 \mu \mathrm{g})$ and penicillin $\mathrm{G}(10 \mathrm{U})$. Plates were incubated at $30{ }^{\circ} \mathrm{C}$ for 2 days.

Cellular polar lipids were extracted as described by Komagata \& Suzuki (1987), separated on silica gel plates (DC Kieselgel 60F; Merck) by using TLC and identified according to their reactions with appropriate detection reagents. Cell biomass of strain $\mathrm{NH}_{3} 6 \mathrm{~A}^{\mathrm{T}}$ for polar lipid analysis was obtained from cultures grown in M2 for 3 days at $30{ }^{\circ} \mathrm{C}$. The polar lipid composition of the isolate is consistent with that given in the emended description of the genus Arenibacter (Nedashkovskaya et al., 2006), consisting mainly of phosphatidylethanolamine.

For cellular fatty acid analysis, strain $\mathrm{NH}_{36 \mathrm{~A}^{\mathrm{T}}}$ was harvested from marine agar 2216 (Difco) plates after cultivation for 3 days at $25{ }^{\circ} \mathrm{C}$. Fatty acids were extracted according to the standard protocol of the Microbial Identification system (MIDI; Sherlock). Analysis of the fatty acid methyl esters was performed by GC (6850; Agilent) and peaks were identified with MIDI software (version 6.0). The predominant cellular fatty acids of strain $\mathrm{NH} 36 \mathrm{~A}^{\mathrm{T}}$ were straight-chain, branched-chain saturated and unsaturated fatty acids, namely $\mathrm{C}_{15: 0}(9.4 \%)$, iso$\mathrm{C}_{15: 0}(11.6 \%)$, iso- $\mathrm{C}_{17: 0} 3-\mathrm{OH}(9.4 \%)$, anteiso- $\mathrm{C}_{15: 0}$

Table 1. Cellular fatty acid compositions (\%) of strain $\mathrm{NH}_{3} 6 \mathrm{~A}^{\top}$ and Arenibacter type strains

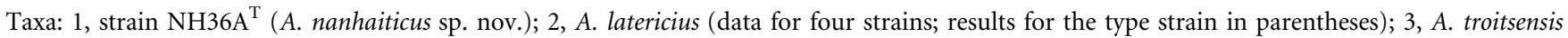
KMM $3674^{\mathrm{T}}$; 4, A. certesii KMM $3941^{\mathrm{T}} ; 5$, A. palladensis $\mathrm{KMM} 3961^{\mathrm{T}} ; 6$, A. echinorum KMM $6032^{\mathrm{T}}$. Data for reference strains are from Nedashkovskaya et al. (2007).

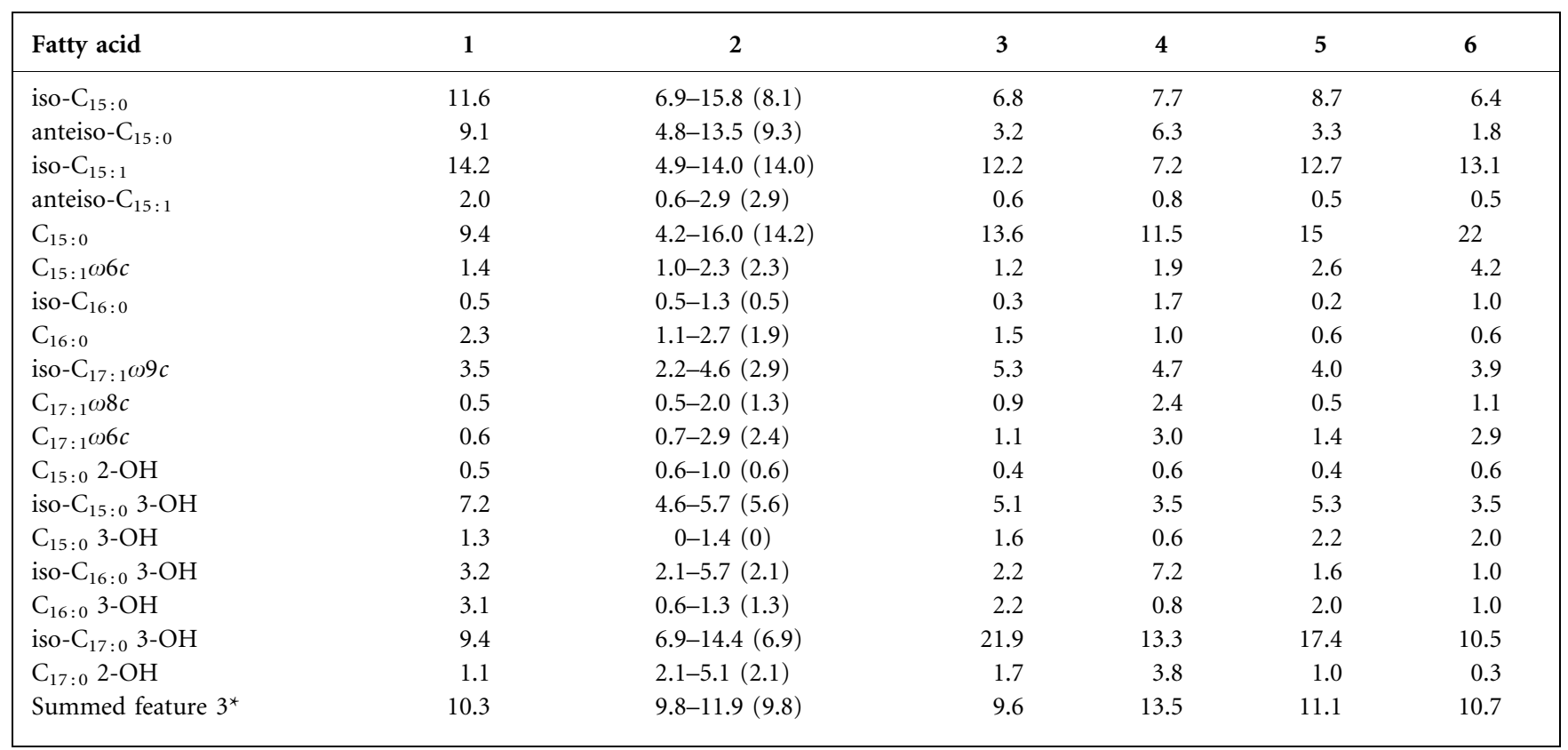

*Summed features are groups of two or three fatty acids that cannot be separated by GC using the MIDI system. Summed feature 3 comprised iso$\mathrm{C}_{15: 0} 2-\mathrm{OH}$ and/or $\mathrm{C}_{16: 1} \omega 7 c$. 
(9.1\%), iso- $\mathrm{C}_{15: 0} 3-\mathrm{OH}(7.2 \%)$, iso- $\mathrm{C}_{15: 1}(14.2 \%)$ and summed feature 3 (10.3\%; comprising iso- $\mathrm{C}_{15: 0} 2-\mathrm{OH}$ and/or $\mathrm{C}_{16: 1} \omega 7 c$ ). The presence of a significant amount of iso- $\mathrm{C}_{17: 0} 3-\mathrm{OH}\left(9.4 \%\right.$ in strain $\mathrm{NH} 36 \mathrm{~A}^{\mathrm{T}} ; 6.9-21.9 \%$ in the type strains of the five Arenibacter species) supports placement of the isolate in the family Flavobacteriaceae (Nedashkovskaya et al., 2006). This fatty acid profile was similar to those of the type strains of Arenibacter species, although there were differences in the proportions of some fatty acids (Table 1). These chemotaxonomic data show that strain $\mathrm{NH} 36 \mathrm{~A}^{\mathrm{T}}$ appears to belong to the genus Arenibacter.

Genomic DNA was prepared from cells cultivated on M2 agar plates according to the extraction protocol described by Ausubel et al. (1995). To detect the precise taxonomic position of the isolate, the almost-full-length 16S rRNA gene sequence was determined by PCR amplification and subjected to sequencing. The determined sequences were aligned manually with reference $16 \mathrm{~S}$ rRNA gene sequences available in GenBank and evolutionary distances were then computed by using the program DNAMAN with the Kimura two-parameter correction (Kimura, 1980); a phylogenetic tree was constructed (Fig. 1) according to the neighbourjoining method (Saitou \& Nei, 1987). To evaluate the phylogenetic tree, bootstrap analysis with 1000 sample replications was performed.
The DNA G + C content of strain NH36 ${ }^{\mathrm{T}}$ was $38.9 \mathrm{~mol} \%$, determined by reversed-phase HPLC according to the method of Tamaoka \& Komagata (1984), which is in the range for members of the genus Arenibacter (Table 2).

Morphological, physiological and biochemical characteristics of strain $\mathrm{NH} 36 \mathrm{~A}^{\mathrm{T}}$ are given in the species description and Table 2. Cells were rod-shaped and motile by means of gliding (Fig. 2). The isolate grew well on M2 medium. Colonies were circular, moist-appearing and convex with an entire margin and a smooth surface. Cell growth occurred at salinities of $0.5-6.5 \%(\mathrm{w} / \mathrm{v})$. Optimal growth occurred in the presence of $0.5-4.0 \%(\mathrm{w} / \mathrm{v}) \mathrm{NaCl}$. No growth occurred in the absence of $\mathrm{NaCl}$ or above $8 \%(\mathrm{w} / \mathrm{v})$ $\mathrm{NaCl}$. Within the tested temperature range $\left(4-45^{\circ} \mathrm{C}\right)$, growth occurred at $10{ }^{\circ} \mathrm{C}$, but not at $45^{\circ} \mathrm{C}$, with optimum growth at $30{ }^{\circ} \mathrm{C}$. Optimal growth occurred between $\mathrm{pH} 7.0$ and 8.5. Weak growth occurred at $\mathrm{pH} 6.1$ and 9.6, but there was no growth at $\mathrm{pH} 5.5$ or 10.0. Strain $\mathrm{NH} 36 \mathrm{~A}^{\mathrm{T}}$ could be distinguished from other Arenibacter species by its inability to utilize L-arabinose, the absence of $\beta$-glucosidase and susceptibility to penicillin G. In addition, the inability to generate acid from D-glucose or L-rhamnose, susceptibility to ampicillin and the requirement of $\mathrm{Na}^{+}$ions for growth distinguished this strain from $A$. palladensis and $A$. echinorum; motility by gliding, the failure to reduce nitrate, and the absence of $\alpha$-chymotrypsin and urease activities

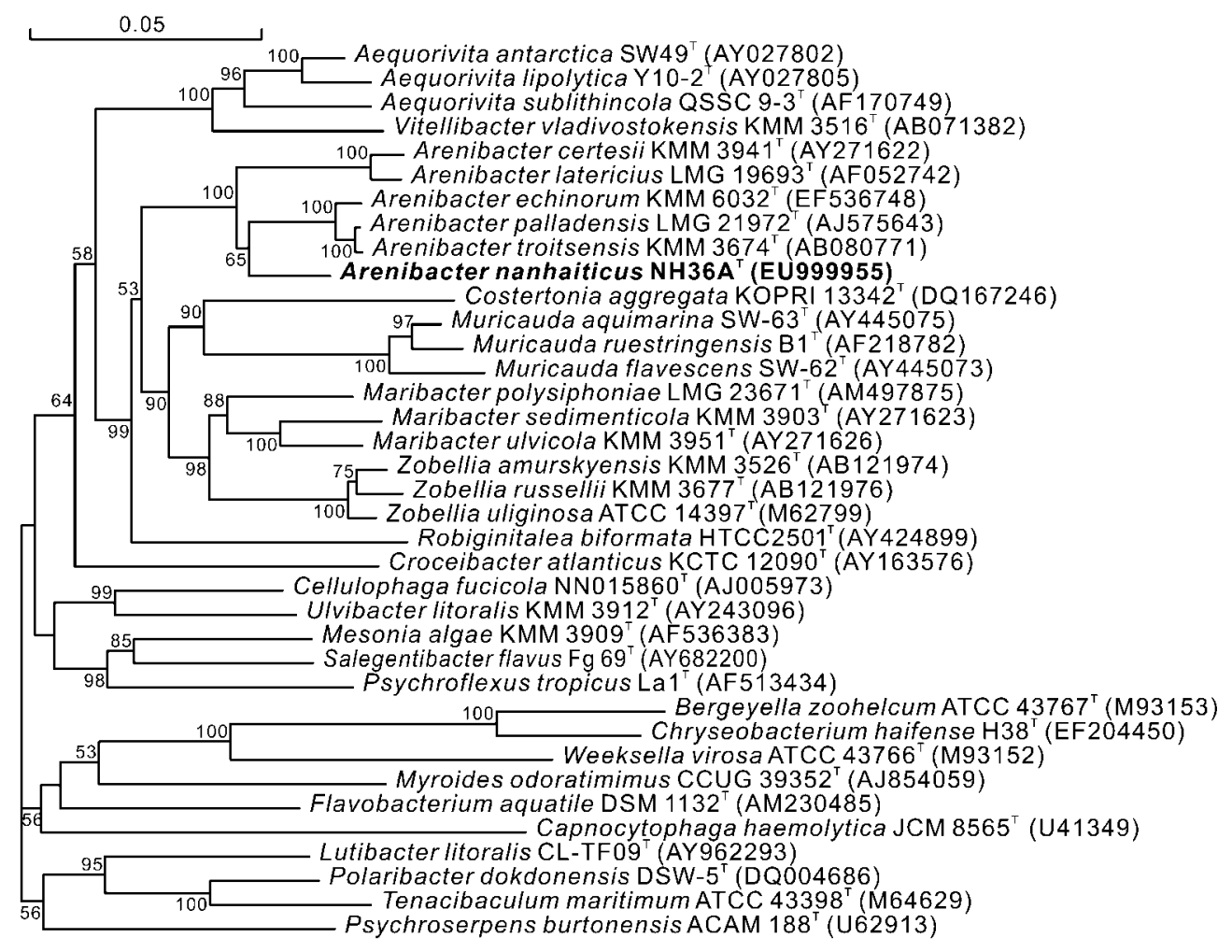

Fig. 1. Neighbour-joining tree based on $16 \mathrm{~S}$ rRNA gene sequences showing the relationship between strain $N H 36 A^{\top}$ and strains of related species belonging to the family Flavobacteriaceae. Only bootstrap values above $50 \%$ are shown (1000 resamplings) at branch points. Bar, 0.05 substitutions per nucleotide position. 


\section{Table 2. Phenotypic characteristics that distinguish Arenibacter nanhaiticus $\mathrm{NH}_{36} \mathrm{~A}^{\top}$ from other Arenibacter species}

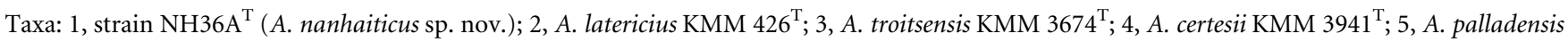
KMM $3961^{\mathrm{T}} ; 6$, A. echinorum KMM 6032 ${ }^{\mathrm{T}}$. Data are from Ivanova et al. (2001), Nedashkovskaya et al. $(2003,2004,2006,2007)$ and this study. All strains are positive for the following: respiratory-type metabolism; oxidase, catalase, acid and alkaline phosphatases, $\alpha$ - and $\beta$-galactosidases, $\alpha$ glucosidase, $N$-acetyl- $\beta$-glucosaminidase, leucine arylamidase, valine arylamidase, cystine arylamidase, trypsin, naphthol-AS-BI-phosphohydrolase, $\alpha$-mannosidase and $\alpha$-fucosidase; utilization of D-glucose, D-lactose, trehalose, raffinose and D-mannose; and susceptibility to lincomycin and resistance to kanamycin, gentamicin, neomycin and polymyxin B. All strains are negative for the following: arginine dihydrolase, lysine decarboxylase, ornithine decarboxylase and tryptophan deaminase; production of flexirubin-type pigments and indole; degradation of agar, alginate, cellulose, chitin, starch and Tween 80; acid production from inositol and mannitol; and utilization of inositol. + , Positive; - , negative; ND, not determined.

\begin{tabular}{|c|c|c|c|c|c|c|}
\hline Characteristic & 1 & 2 & 3 & 4 & 5 & 6 \\
\hline Gliding motility & + & - & - & - & + & + \\
\hline Cell diameter $(\mu \mathrm{m})$ & $0.45-0.8$ & $0.4-0.6$ & $0.4-0.7$ & $0.4-0.7$ & $0.4-0.5$ & $0.4-0.5$ \\
\hline $\mathrm{Na}^{+}$requirement & + & + & + & + & - & - \\
\hline Nitrate reduction & - & + & + & + & - & - \\
\hline $\mathrm{H}_{2} \mathrm{~S}$ production & - & - & + & - & - & - \\
\hline \multicolumn{7}{|l|}{ Degradation of: } \\
\hline Gelatin & - & - & + & - & - & - \\
\hline Urea & - & + & - & + & - & - \\
\hline Tween 20 & - & - & - & - & - & + \\
\hline Tween 40 & - & - & + & - & - & + \\
\hline \multicolumn{7}{|l|}{ Tolerance to:* } \\
\hline D-Galactose & + & + & $\mathrm{ND}$ & + & + & - \\
\hline Maltose & + & + & - & + & + & + \\
\hline L-Arabinose & - & + & + & + & + & + \\
\hline Glycerol & - & + & - & - & - & - \\
\hline$N$-Acetyl- $\beta$-glucosamine & + & + & - & + & + & - \\
\hline Mannitol & - & - & - & - & - & + \\
\hline Malate & - & - & - & - & - & + \\
\hline Citrate & - & - & - & - & - & + \\
\hline \multicolumn{7}{|l|}{ Acid production from: } \\
\hline D-Glucose & - & + & - & + & + & + \\
\hline Melibiose & - & + & - & + & - & + \\
\hline \multicolumn{7}{|l|}{ Production of: } \\
\hline Carbenicillin & + & + & - & - & - & - \\
\hline Tetracycline & - & - & + & - & - & + \\
\hline Penicillin G & + & - & - & - & - & - \\
\hline Streptomycin & - & - & - & - & $\mathrm{ND}$ & + \\
\hline DNA G $+\mathrm{C}$ content $(\mathrm{mol} \%)$ & 38.9 & $37-38$ & 40 & 37.7 & 40 & $39-40$ \\
\hline
\end{tabular}

${ }^{\star}$ Ranges are given; optimal conditions are indicated in parentheses. 


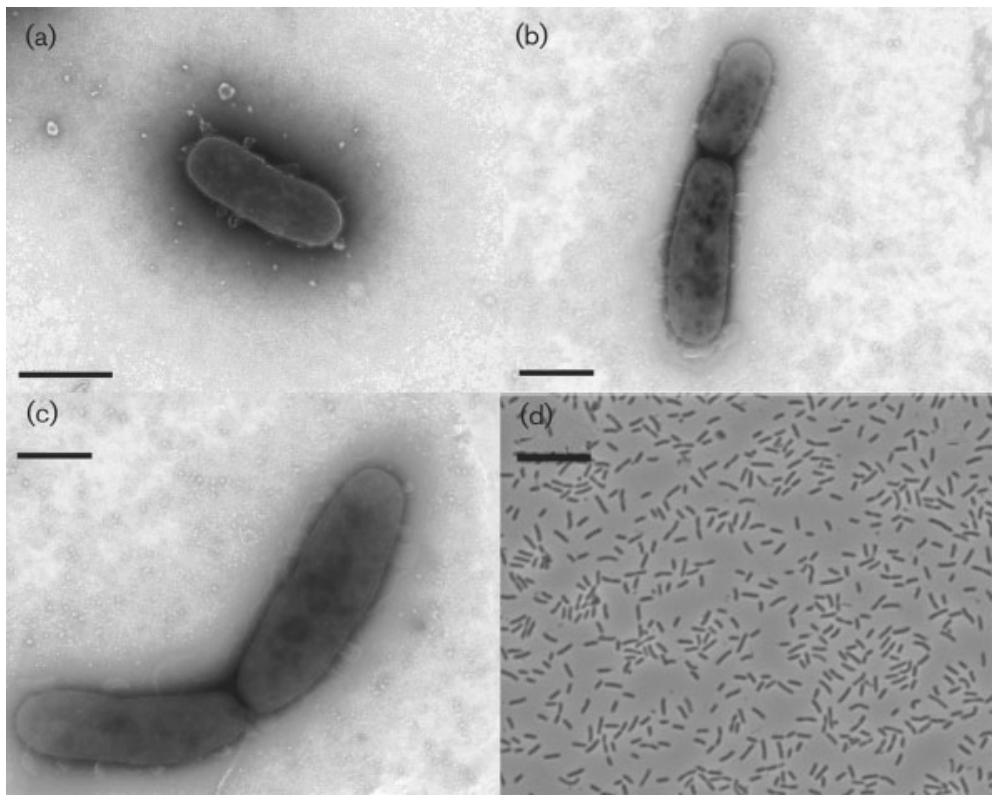

Fig. 2. Microscopic images of strain $\mathrm{NH}_{36} \mathrm{~A}^{\top}$ (A. nanhaiticus sp. nov.). (a-c) Transmission electron micrographs of negatively stained cells grown on $\mathrm{M} 2$ agar medium for $24 \mathrm{~h}$ at $30{ }^{\circ} \mathrm{C}$; bars, $1 \mu \mathrm{m}$. (d) Photomicrograph of vegetative cells viewed by phase-contrast microscopy; bar, $10 \mu \mathrm{m}$.

separated the isolate from A. latericius, A. troitsensis and A. certesii.

The 16S rRNA gene sequence of strain $\mathrm{NH}_{36} \mathrm{~A}^{\mathrm{T}}$ comprising 1464 nt was determined after PCR amplification. The isolate showed highest $16 \mathrm{~S}$ rRNA gene sequence similarities with the type strains of members of the genus Arenibacter: $96.2 \%$ with $A$. palladensis, $96.0 \%$ with $A$. echinorum, $95.8 \%$ with $A$. troitsensis, and $94.3 \%$ with $A$. certesii and A. latericius. Other members of the family Flavobacteriaceae were even more distantly related to strain $\mathrm{NH}_{36 \mathrm{~A}^{\mathrm{T}}}$, with $16 \mathrm{~S}$ rRNA gene sequence similarities of $\leqslant 92.1 \%$ (92.1\% similarity with Maribacter sedimenticola KMM $3903^{\mathrm{T}}$ ). Phylogenetic analysis of 16S rRNA gene sequences from organisms with validly published names revealed that strain $\mathrm{NH}_{3} 6 \mathrm{~A}^{\mathrm{T}}$ and the five recognized species of Arenibacter belonged to the same clade. Within the clade, strain $\mathrm{NH}_{36 \mathrm{~A}^{\mathrm{T}}}$, A. echinorum, A. troitsensis and A. palladensis formed a separate subclade, which clustered robustly ( $100 \%$ bootstrap support, 1000 replicates) with the branch formed by $A$. latericius and $A$. certesii (Fig. 1). The same topology was also found in trees based on the maximum-likelihood and maximum-parsimony algorithms (data not shown). The results of phylogenetic analysis and the relative low 16S rRNA gene sequence similarities to Arenibacter species (94.3-96.2\%) suggest that strain $\mathrm{NH} 36 \mathrm{~A}^{\mathrm{T}}$ represents a novel species within the genus Arenibacter.

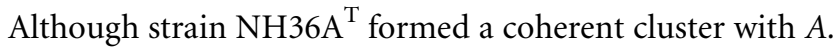
echinorum, $A$. palladensis and $A$. troitsensis at a low bootstrap resampling value of $65 \%$, identical morphological, physiological and chemotaxonomic characteristics (Tables 1 and 2) strongly support placing strain $\mathrm{NH}_{36 \mathrm{~A}^{\mathrm{T}}}$ in the genus Arenibacter. Hence, it is proposed that strain NH36A ${ }^{\mathrm{T}}$ represents a novel species in the genus Arenibacter, Arenibacter nanhaiticus sp. nov.

\section{Description of Arenibacter nanhaiticus sp. nov.}

Arenibacter nanhaiticus (nan.hai'ti.cus. N.L. masc. adj. nanhaiticus pertaining to Nanhai, the Chinese name for the South China Sea, the site where the type strain was isolated).

Cells are aerobic, Gram-stain-negative rods $(0.45-0.8 \mu \mathrm{m}$ wide and 1.4-3.8 $\mu \mathrm{m}$ long) that are motile by means of gliding. Colonies on M2 are circular, moist-appearing, glistening with a smooth surface, low convex with entire margins, dark orange in colour and $1-3 \mathrm{~mm}$ in diameter after 5 days incubation at $30{ }^{\circ} \mathrm{C}$. Growth occurs at 10 $40{ }^{\circ} \mathrm{C}$ and $\mathrm{pH}$ 6.1-9.6. The optimal temperature for growth is $30{ }^{\circ} \mathrm{C}$. Optimal $\mathrm{pH}$ for growth is 7.0-8.5. $\mathrm{NaCl}$ is essential for growth. Growth is detected in the presence of $0.5-6.5 \%(\mathrm{w} / \mathrm{v}) \mathrm{NaCl}$. The optimal $\mathrm{NaCl}$ concentration for growth is $0.5-4.0 \%$. Flexirubin-type pigments are not produced. Positive for oxidase and catalase. Negative for nitrate reduction, hydrolysis of starch, gelatin liquefaction and urease activity. $\mathrm{H}_{2} \mathrm{~S}$ and indole are not produced. In assays with the API $20 \mathrm{E}$ system, $\beta$-galactosidase is positive. Negative for arginine dihydrolase, lysine decarboxylase, ornithine decarboxylase and tryptophan deaminase. In API ZYM strips, alkaline phosphatase, leucine arylamidase, valine arylamidase, cystine arylamidase, acid phosphatase, naphthol-AS-BI-phosphohydrolase, $N$-acetyl- $\beta$-glucosaminidase, $\alpha$-mannosidase and $\alpha$-fucosidase activities are positive. Trypsin, $\alpha$-galactosidase and $\alpha$-glucosidase are weakly positive. Esterase (C4), esterase lipase (C8), lipase (C14), $\alpha$-chymotrypsin, $\beta$-glucuronidase and $\beta$-glucosidase are negative. The Voges-Proskauer test is positive. In Biolog GN2 microplates, positive for oxidation of dextrin, $\mathrm{N}$-acetyl-D-galactosamine, $\mathrm{N}$-acetyl-D-glucosamine, adonitol, D-arabitol, cellobiose, D-fructose, D-galactose, gentiobiose, $\alpha$-D-glucose, $\alpha$-D-lactose, lactulose, maltose, 
D-mannose, methyl $\beta$-D-glucoside, raffinose, D-sorbitol, sucrose, trehalose, turanose and acetic acid. L-Glutamic acid is oxidized weakly. Susceptible to cefoperazone, clindamycin, ciprofloxacin, ceftriaxone, erythromycin, lincomycin, furazolidone, ampicillin, cephazolin, carbenicillin, rifampicin, piperacillin, penicillin $\mathrm{G}$, chloramphenicol and doxycycline hydrochloride, but resistant to cephalexin, kanamycin, norfloxacin, tetracycline, metronidazole, minocycline, vancomycin, streptomycin, polymyxin B, ofloxacin, trimethoprim, oxacillin, cephradine, gentamicin and neomycin. Predominant fatty acids are straight-chain unsaturated and saturated, and branchedchain unsaturated and saturated fatty acids, namely iso$\mathrm{C}_{15: 1}$, iso- $\mathrm{C}_{15: 0}, \mathrm{C}_{15: 0}$, iso- $\mathrm{C}_{17: 0} 3-\mathrm{OH}$, anteiso- $\mathrm{C}_{15: 0}$, iso$\mathrm{C}_{15: 0} 3-\mathrm{OH}$, iso- $\mathrm{C}_{17: 1} \omega 9 c$, iso- $\mathrm{C}_{16: 0} 3-\mathrm{OH}, \mathrm{C}_{16: 0} 3-\mathrm{OH}$, $\mathrm{C}_{16: 0}$ and summed feature 3 (comprising iso- $\mathrm{C}_{15: 0} 2-\mathrm{OH}$ and/or $\mathrm{C}_{16: 1} \omega 7 c$ ). The major polar lipid is phosphatidylethanolamine. Other phenotypic characteristics are given in Table 2.

The type strain is $\mathrm{NH}_{36 \mathrm{~A}^{\mathrm{T}}}$ (=LMG $24842^{\mathrm{T}}=\mathrm{CCTCC} \mathrm{AB}$ $208315^{\mathrm{T}}=$ MCCC $1 \mathrm{~A} 04137^{\mathrm{T}}$ ), isolated from a sandy sediment sample from the South China Sea. The DNA G + C content of the type strain is $38.9 \mathrm{~mol} \%$ (determined by HPLC).

\section{Acknowledgements}

This work was supported financially by the National Key Technology R\&D Program of China (no. 2006BAB19B02) and the National Infrastructure of Natural Resources for Science and Technology Program of China (no. 2005DKA21209).

\section{References}

Ausubel, F. M., Brent, R., Kingston, R. E., Moore, D. D., Seidman, J. G., Smith, J. A. \& Struhl, K. (editors) (1995). Short Protocols in Molecular Biology: a Compendium of Methods from Current Protocols in Molecular Biology, 3rd edn. New York: John Wiley.

Christakis, G. B., Perlorentzou, S. P., Chalkiopoulou, I., Athanasiou, A. \& Legakis, N. J. (2005). Chryseobacterium indologenes non-catheterrelated bacteremia in a patient with a solid tumor. J Clin Microbiol 43, 2021-2023.
Cowan, S. T. \& Steel, K. J. (1965). Manual for the Identification of Medical Bacteria. London: Cambridge University Press.

Ivanova, E. P., Kiprianova, E. A., Mikhailov, V. V., Levanova, G. F., Garagulya, A. D., Gorshkova, N. M., Vysotskii, M. V., Nicolau, D. V., Yumoto, N. \& other authors (1998). Phenotypic diversity of Pseudoalteromonas citrea from different marine habitats and emendation of the description. Int J Syst Bacteriol 48, 247-256.

Ivanova, E. P., Nedashkovskaya, O. I., Chun, J., Lysenko, A. M., Frolova, G. M., Svetashev, V. I., Vysotskii, M. V., Mikhailov, V. V., Huq, A. \& Colwell, R. R. (2001). Arenibacter gen. nov., new genus of the family Flavobacteriaceae and description of a new species, Arenibacter latericius sp. nov. Int J Syst Evol Microbiol 51, 1987-1995.

Kimura, M. (1980). A simple method for estimating evolutionary rates of base substitutions through comparative studies of nucleotide sequences. J Mol Evol 16, 111-120.

Komagata, K. \& Suzuki, K. (1987). Lipid and cell-wall analysis in bacterial systematics. Methods Microbiol 19, 161-207.

Nedashkovskaya, O. I., Suzuki, M., Vysotskii, M. V. \& Mikhailov, V. V. (2003). Arenibacter troitsensis sp. nov., isolated from marine bottom sediment. Int J Syst Evol Microbiol 53, 1287-1290.

Nedashkovskaya, O. I., Kim, S. B., Han, S. K., Lysenko, A. M., Mikhailov, V. V. \& Bae, K. S. (2004). Arenibacter certesii sp. nov., a novel marine bacterium isolated from the green alga Ulva fenestrata. Int J Syst Evol Microbiol 54, 1173-1176.

Nedashkovskaya, O. I., Vancanneyt, M., Cleenwerck, I., Snauwaert, C., Kim, S. B., Lysenko, A. M., Shevchenko, L. S., Lee, K. H., Park, M. S. \& other authors (2006). Arenibacter palladensis sp. nov., a novel marine bacterium isolated from the green alga Ulva fenestrata, and emended description of the genus Arenibacter. Int J Syst Evol Microbiol 56, 155160.

Nedashkovskaya, O. I., Kim, S. B., Lysenko, A. M., Lee, K. H., Bae, K. S. \& Mikhailov, V. V. (2007). Arenibacter echinorum sp. nov., isolated from the sea urchin Strongylocentrotus intermedius. Int J Syst Evol Microbiol 57, 2655-2659.

Saitou, N. \& Nei, M. (1987). The neighbor-joining method: a new method for reconstructing phylogenetic trees. Mol Biol Evol 4, 406425.

Sambrook, J., Fritsch, E. F. \& Maniatis, T. (1989). Molecular Cloning: a Laboratory Manual, 2nd edn. Cold Spring Harbor, NY: Cold Spring Harbor Laboratory.

Tamaoka, J. \& Komagata, K. (1984). Determination of DNA base composition by reversed-phase high-performance liquid chromatography. FEMS Microbiol Lett 25, 125-128. 